\author{
G. R. Holstein · G. P. Martinelli · R. Boyle • \\ R. D. Rabbitt · S. M. Highstein
}

\title{
Ultrastructural observations of efferent terminals in the crista Ampullaris of the toadfish, opsanus tau
}

Published online: 20 May 2004

(C) Springer-Verlag 2004

\begin{abstract}
The present study was conducted to visualize the ultrastructural features of vestibular efferent boutons in the oyster toadfish, Opsanus tau. The crista ampullaris of the horizontal semicircular canal was processed for and examined by routine transmission electron microscopy. The results demonstrate that such boutons vary in size and shape, and contain a heterogeneous population of lucent vesicles with scattered dense core vesicles. Efferent contacts with hair cells are characterized by local vesicle accumulations in the presynaptic terminal and a subsynaptic cistern in the postsynaptic region of the hair cell. Serial efferent to hair cell to afferent synaptic arrangements are common, particularly in the central portion of the crista. However, direct contacts between efferent terminals and afferent neurites were not observed in our specimens. The existence of serial synaptic contacts, often with a row of vesicles in the efferent boutons lining the efferent-afferent membrane apposition, suggests that the
\end{abstract}

The online version of the original article can be found at http://dx. doi.org/10.1007/s00221-003-1734-8

G. R. Holstein $(\bowtie) \cdot$ G. P. Martinelli

Department of Neurology, Mount Sinai School of Medicine, One Gustave L. Levy Place,

Box 1140, New York, NY 10029, USA

e-mail: gay.holstein@mssm.edu

Tel.: +1-212-2417072

Fax: +1-212-9873937

R. Boyle

NASA Ames BioVIS Technology Center,

Moffett Field, CA 94035, USA

R. D. Rabbitt

Department of Bioengineering, University of Utah,

Salt Lake City, UT 84112, USA

S. M. Highstein

Department of Otolaryngology and Neurobiology, Washington University, St. Louis,

MO 62103, USA

S. M. Highstein

Marine Biological Laboratory,

Woods Hole, MA, USA efferent influence on the crista may involve both synaptic and nonsynaptic, secretory mechanisms. Further, it is suggested that differences in more subtle aspects of synaptic architecture and/or transmitter and receptor localization and interaction may render the efferent innervation of the peripheral crista less effective in influencing sensory processing.

Keywords Vestibular morphology · Inner ear · Semicircular canal $\cdot$ Nervous system $\cdot$ Balance

\section{Exp Brain Res (2004) 155:265-273}

Due to technical problems, in the printed version, the illustrations were not printed properly. For this reason, the complete article will be reprinted here.

\section{Introduction}

The crista ampullaris of the toadfish horizontal semicircular canal is an inverted saddle-shaped structure which extends across the ampullary enlargement and is anchored at its distal end to the ampullary wall (for a detailed description, see Boyle et al. 1991). Sensory hair cells and supporting cells form a compact receptor sheet that is estimated to be $\sim 940 \mu \mathrm{m}$ long, and varying in width from $\sim 250-300 \mu \mathrm{m}$ at the proximal and distal ends, respectively, to $\sim 130 \mu \mathrm{m}$ at the central isthmus (Boyle et al. 1991). Classically, two types of receptor cells have been distinguished in the cristae of amniotes (reptiles, birds and mammals): flask-shaped type I and cylindrical type II hair cells. Type I cells are surrounded on all but their apical surfaces by specialized enlargements of the primary afferent distal neuritic endings called nerve chalices or calyces (Wersäll 1954; Engström 1960; Hamilton 1968). Type II hair cells contact small bouton endings of primary afferent neurites and the outer faces of neighboring calyces (Spoendlin 1965; Engström 1970; Ross et al. 1985). Anamniotes (fish and amphibians) such as the toadfish 


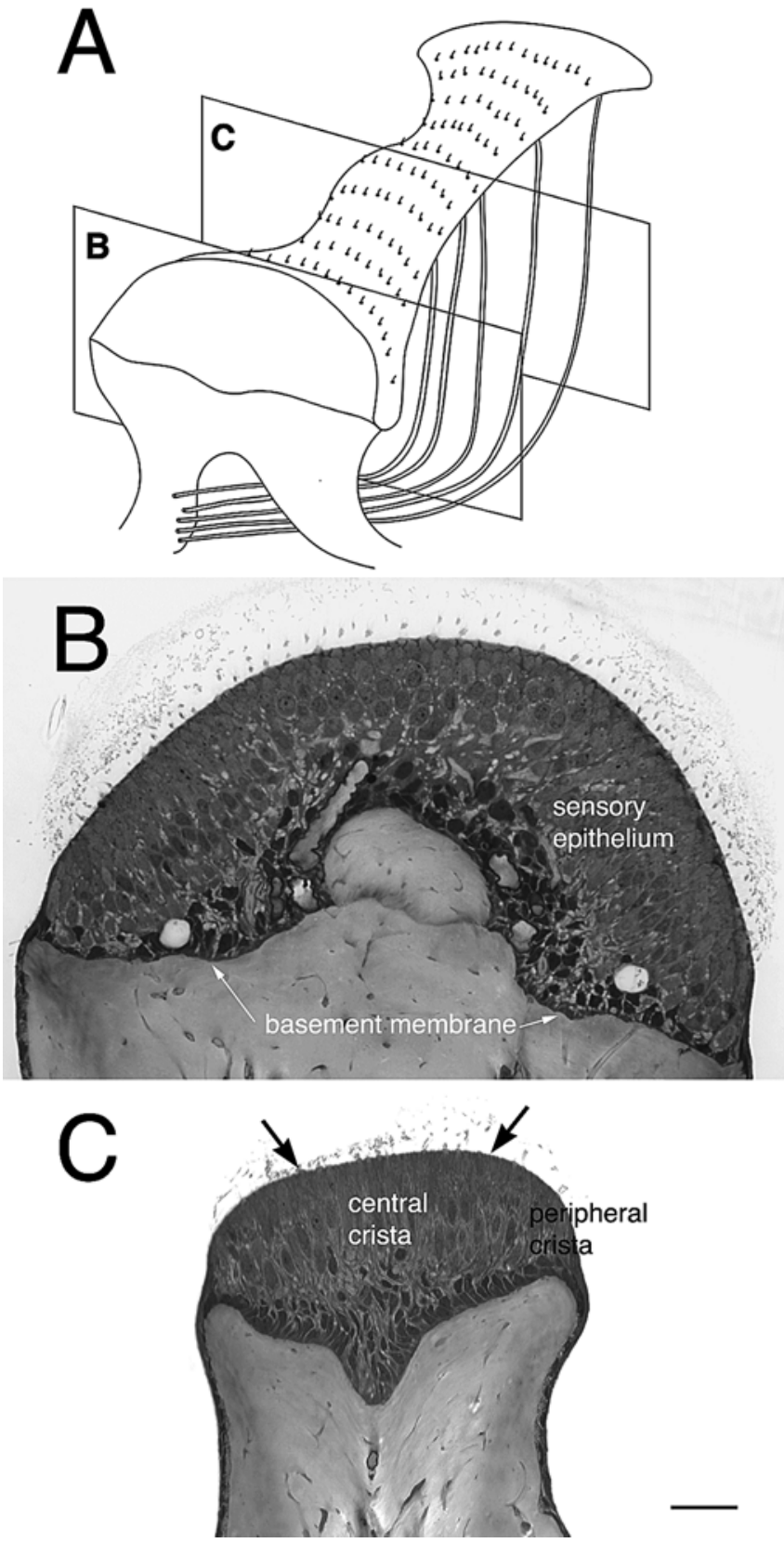

Fig. 1 A Schematic of the toadfish horizontal canal crista ampullaris, with the approximate locations of the two sections in $\mathrm{B}$ and $\mathrm{C}$ indicated. $\mathbf{B}, \mathbf{C}$ One- $\mu \mathrm{m}$ thick survey sections from a resinembedded toadfish horizontal canal crista, estimated to be $1,008 \mu \mathrm{m}$ in total length, stained with $1 \%$ methylene blue/1\% Azur II in $1 \%$ $\mathrm{Na}_{2} \mathrm{BrO}_{7}$. B A section through the peripheral crista, obtained approximately $55 \mu \mathrm{m}$ proximal to the first appearance of hair cells at the distal margin of the crista. C A section obtained approximately $540 \mu \mathrm{m}$ from the distal margin of the same crista, through the isthmus. The arrows indicate the middle $50 \%$ of the width of the crista. Black scale bar: $25 \mu \mathrm{m}$ for both micrographs

have traditionally been described as having only type IIlike elements (Wersäll 1960; Flock 1964; Gleisner et al. 1973). Since the presence of a nerve chalice has often been used as the signal feature to distinguish Type I from Type II hair cells in amniotes, the absence of this calyx in anamniotes has been used to support the classic notion that only one type of hair cell is present in these animals (Wersäll 1960; Flock 1964). However, there is increasing evidence for the existence of a multiplicity of morphologically defined hair cell types in anamniotes (Popper 2000). Although early ultrastructural studies did indeed demonstrate the existence of morphologic variations in the hair cells of bony fishes (Flock 1964; Lowenstein et al. 1968; Wegner 1982), the demonstration that these might not all be variants of mammalian type II cells is more recent (Saidel and Presson 1990; Saidel et al. 1990; Chang et al. 1992; Lanford and Popper 1996; Saidel and Crowder 1997) and suggests that a revision of the classic scheme is in order. Synapses between hair cells and primary afferents occur at morphologically discrete contacts that are often distinguished by the presence of a synaptic body with a halo of electron-lucent vesicles in the receptor cell, and a postsynaptic density associated with the afferent terminal membrane (Sans and Highstein 1984).

Vestibular end organs receive CNS innervation from several cell groups located in the caudal brainstem (Highstein and Baker 1986) (for review, see Goldberg et al. 2000). In amniotes, these efferent axons terminate both on the nerve chalice, forming classic morphologic synapses with symmetrical membrane thickenings, and directly on type II hair cells. Direct hair cell contacts involve a synaptic complex that includes a flattened subsynaptic cistern subjacent to the hair cell membrane (Smith and Sjostrand 1961; Hama 1965; Nakajima and Wang 1974). Electrical stimulation of the efferent vestibular system (EVS) in toadfish affects the discharge of primary afferents and their responses to head movements (Highstein and Baker 1986; Boyle and Highstein 1990). During EVS activation, the firing rates of acceleration and high gain afferents are increased up to fourfold, while simultaneously the amplitude or sensitivity of their responses to head velocity is scaled downward by about $20 \%$. Low gain afferents show a slight increase in firing rate, on average $25 \%$, and their responses to head velocity are essentially unchanged. It has been suggested that this increase in afferent firing rate may be attributable to direct efferent contacts on afferent endings (Highstein and Baker 1985), whereas the reduction in sensitivity may be due to the hyperpolarizing action of efferent synapses onto hair cells (Russell 1971). In the toadfish, two morphological types of brainstem efferent terminals and contacts have been described previously (Sans and Highstein 1984). Efferent synapses onto hair cells reportedly involve terminals with round synaptic vesicles and electron-dense particles presynaptic to hair cell membranes with associated subsynaptic cisterns, whereas efferent terminals with round lucent microvesicles and some dense core vesicles form synapses directly with afferent endings. The present study was conducted to re-examine the synaptology of the efferent endings in the toadfish crista ampullaris. Preliminary findings were reported in abstract form (Holstein and Highstein 1999; Holstein et al. 2000). 


\section{Materials and methods}

The tissue for this study was obtained from twelve adult oyster toadfish (Opsanus tau) of either gender (approximately $500 \mathrm{gm}$ ) obtained from the Marine Biological Laboratory (Woods Hole, MA, USA). The experiments were approved by the Institutional Animal Care and Use Committee at the Marine Biological Laboratory and were conducted in accordance with the NIH Guide for the Care and Use of Laboratory Animals (NIH Publications No. 80-23, Rev. 1996).

Toadfish were anesthetized by immersion in MS $222(25 \mathrm{mg} / \mathrm{L}$ sea water, 3-aminobenzoic acid ethyl ester; Sigma, St. Louis, MO, USA), partially immobilized by intramuscular injection of pancuronium bromide $(0.05 \mathrm{mg} / \mathrm{kg}$, ), and heparinized $(1 \mathrm{ml}$ of $500 \mathrm{U}$ diluted to $50 \%$ in saline) by injection into the conus through a $30 \mathrm{G}$ needle. A blunt perfusion needle (18G), attached via silicon tubing to a variable speed peristaltic pump, was inserted into the conus. The vasculature was flushed for 2-3 min with approximately $50 \mathrm{ml}$ of room temperature (RT) cacodylate-buffered saline (0.01 M, pH 7.3) containing $5 \%$ sucrose and $2 \mu \mathrm{M}$ sodium nitroprusside, and then perfusion continued with injection of $300 \mathrm{ml}$ of RT fixative $(4 \%$ paraformaldehyde $/ 3 \%$ glutaraldehyde $)$ in cacodylate buffer $(0.1 \mathrm{M}$, $\mathrm{pH} 7.4$ ) delivered at $18 \mathrm{ml} / \mathrm{min}$, followed by $300 \mathrm{ml}$ of the same fixative at $4{ }^{\circ} \mathrm{C}$ delivered at the same rate.

After completion of the perfusion, a dorsal craniotomy was performed to expose the vestibular labyrinths. The dura was opened and an additional $5 \mathrm{ml}$ of perfusion fixative was injected over the region of the labyrinths and left in situ for $10 \mathrm{~min}$. The semicircular canals were then removed from the skull and placed in vials of glutaraldehyde-free fixative (immersion fixative) for $2 \mathrm{~h}$ at $4^{\circ} \mathrm{C}$. The ampullae were subsequently dissected from the canals and placed in vials of fresh immersion fixative at $4^{\circ} \mathrm{C}$ for $12 \mathrm{~h}$. The end organs were then osmicated $\left(1 \% \mathrm{OsO}_{4}\right)$, dehydrated, infiltrated with EponAraldite resin, embedded as whole-mounts, and cured at $56^{\circ} \mathrm{C}$ for 4 days. No en bloc or post-microtomy staining was performed. As a result, the sections have low contrast but are free of staining artifact.

Sections of the resin-embedded tissue were cut by ultramicrotome (Leica UCT) in the transverse plane, perpendicular to the long axis of the crista, and mounted on Formvar-coated slot grids. The following sectioning strategy was utilized: (1) five microns of sensory epithelium were thin-sectioned, which usually required 80 85 sections of 60 -nm thickness each; (2) a 1- $\mu$ m survey section was cut and then $50 \mu \mathrm{m}$ (in peripheral crista) or $40 \mu \mathrm{m}$ (in central crista) of tissue were discarded; (3) another 1- $\mu$ m survey section was cut, and then another $5 \mu \mathrm{m}$ of tissue was thin-sectioned as above. This cutting sequence was repeated until the entire crista was sectioned. The 60-nm section thickness aided resolution, but further decreased contrast in the micrographs. Tissue from the peripheral (Fig. 1A) and central (Fig. 1B) regions of the crista was collected and examined separately. The $1-\mu \mathrm{m}$ survey sections were collected on glass slides, stained with $1 \%$ methylene blue/1\% Azur II in $1 \% \mathrm{Na}_{2} \mathrm{BrO}_{7}$, dehydrated, coverslipped using DPX (BDH Laboratories, Poole, England), examined using a Zeiss Axiophot light microscope, and documented using a Spot (Diagnostic Instruments) digital camera. Thin sections were examined and photographed using a transmission electron microscope (Hitachi H7500). All electron microscope negatives were printed for analysis; those used as illustrations in this manuscript were subsequently digitized using an Agfa Duoscan T2500 scanner. All digital images were prepared as figures using Adobe Photoshop. Before printing, such images were adjusted for brightness, contrast, evenness, and balance across panels in multiple panel figures using only those methods that are analogous to routine wet darkroom techniques.

\section{Results}

Cells and endings were identified solely on the basis of ultrastructural criteria. Hair cells in the toadfish crista are distinguished from supporting cells by the presence of a

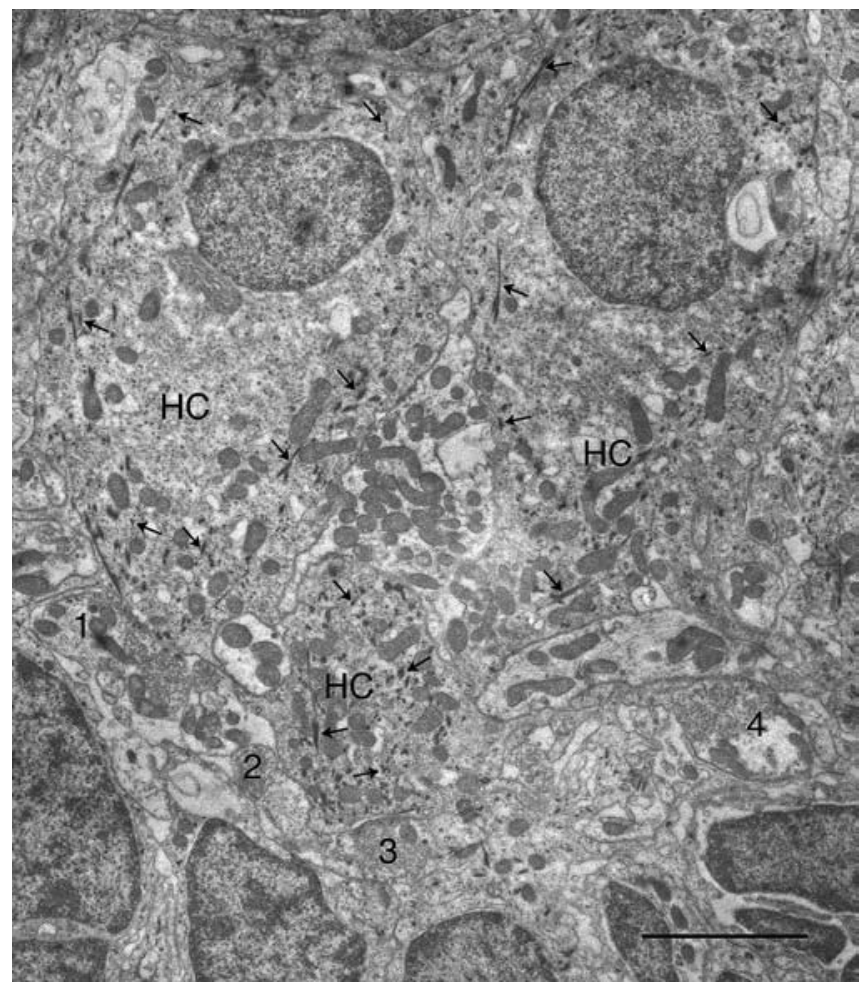

Fig. 2 A low-magnification electron micrograph of a transverse section through the horizontal canal crista, approximately $56 \mu \mathrm{m}$ proximal to the peripheral margin. Three hair cell bodies $(H C)$ and four efferent boutons (numbered 1-4) are apparent in the figure. All four boutons are located deep in the crista, just above the nuclei of the supporting cells. The toadfish hair cells are characterized by the presence of a dense system of filaments that stream in three dimensions through the cytoplasm, particularly in the hypolemmal region (arrows). When cut in cross section, these filaments have the appearance of short tic marks. Filaments can be seen at higher magnification in Figs. 6, 7 and 8. Scale bar: $2.5 \mu \mathrm{m}$

cuticular plate, round nuclei, and ample cytoplasm containing a variety of cellular organelles. Filaments and microtubules of variable length course through the cytoplasm of the hair cell body in three dimensions, particularly in the outer margins of the soma (Fig. 2). These organelles do not appear to be present in mammalian hair cells, but are a prominent feature of the cytoplasm in hair cells of the cristae ampullares in goldfish (Lanford and Popper 1996) and toadfish (Sans and Highstein 1984), and the saccular maculae of goldfish (Hama 1969) and catfish (Jenkins 1979). Somal spines or leaflets often interdigitate between adjacent efferent and afferent endings. As noted by other investigators using similar tissue processing techniques (Hama 1969; Chang et al. 1992; Lysakowski 1996; Lysakowski and Goldberg 1997; Ross 1997), the distinction between efferent and afferent endings is usually straightforward. Profiles of afferent endings have electron-lucent cytoplasm and occasional postsynaptic densities seen in association with hair cell-afferent synaptic body synapses. Efferent terminals have denser cytoplasm and are highly vesiculated with focal accumulations of presynaptic vesicles in the region generally opposite to the subsynaptic cisterns in the 


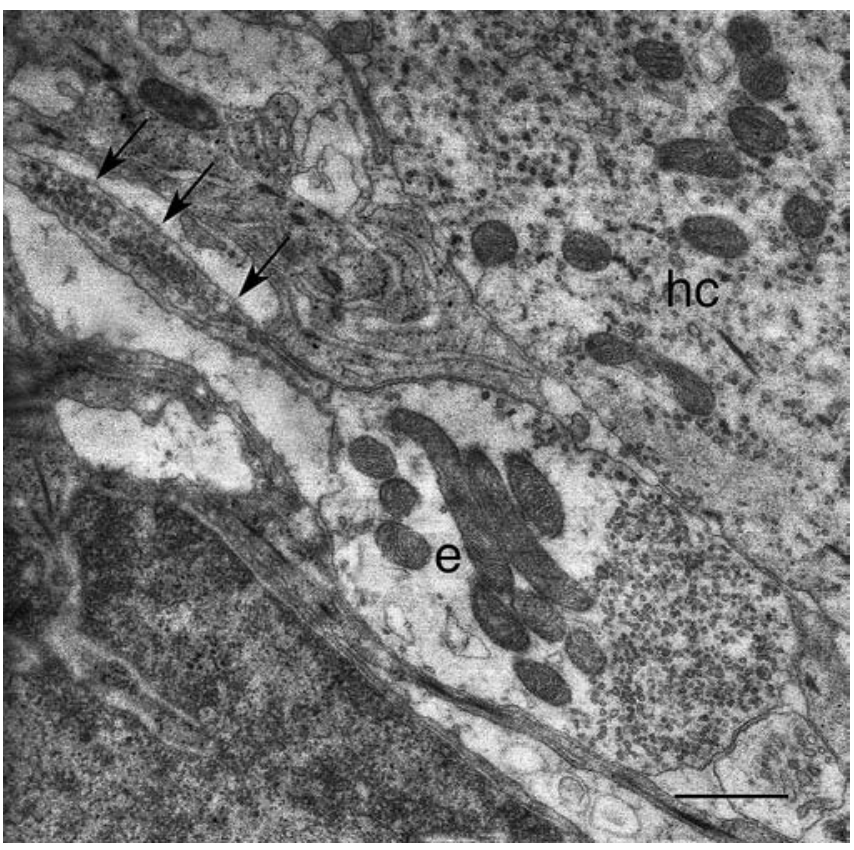

Fig. 3 A paddle-shaped efferent terminal (e) adjacent to a hair cell (hc) in the peripheral crista. Vesicles are compartmentalized in the interconnecting process of the efferent fiber (arrows) and in the bouton head, with mitochondria clustered in the intervening portion of the terminal. Scale bar: $0.7 \mu \mathrm{m}$

Fig. 4A-C Examples of the long, narrow subsynaptic cisterns (arrows) characteristic of synapses formed between efferent boutons $(e)$ and hair cells (hc). A A large mushroomshaped bouton with dense accumulations of round/ovoid synaptic vesicles and scattered dense core vesicles (arrowheads) makes two synaptic contacts with the adjacent hair cell. B, C Additional examples of long, narrow subsynaptic cisterns postsynaptic to efferent terminals of disparate morphology. The terminal in $\mathbf{B}$ has a moderate density of large spherical vesicles; the profile in C contains a cluster of pleomorphic vesicles at the contact site. Scale bars: $0.5 \mu \mathrm{m}$ in $\mathbf{A}$; $0.25 \mu \mathrm{m}$ in $\mathbf{B}, \mathbf{C}$ hair cells. Although vesicle-containing afferent terminals have been reported to form reciprocal synapses with type II hair cells in other systems (Lysakowski 1996; Lysakowski and Goldberg 1997; Ross 1997), no such contacts were observed in our material. The identity of approximately $1 \%$ of the profiles was equivocal; these were excluded from consideration.

Although efferent boutons are present throughout the crista, synaptic contacts involving these terminals are not observed in our material in the most peripheral margins of the epithelium. This comprises $<10 \%$ of the crista, $4-5 \%$ at either longitudinal end. Hair cells in the remaining $91 \%$ of the crista receive direct innervation from efferent vestibular fibers. In general, the efferent boutons are found deep in the epithelium (Fig. 2), near the basement membrane. The synaptic contacts are formed primarily with the basal aspect of the hair cells and occasionally the perinuclear zone, but efferent terminals are not observed to form synapses with the supranuclear or apical portions of the receptor cells.

Most of the efferent boutons are of small size. The cross sectional diameters of the endings average $1.83 \pm 0.6 \mu \mathrm{m}$ (mean \pm standard deviation) and range from $0.6-3.87 \mu \mathrm{m}$ $(\mathrm{N}=314)$. The terminals contain dark tubular mitochondria with narrow intercrestal spaces and a moderate density of round/pleomorphic lucent synaptic vesicles, as well as occasional scattered dense core vesicles. The mitochondria
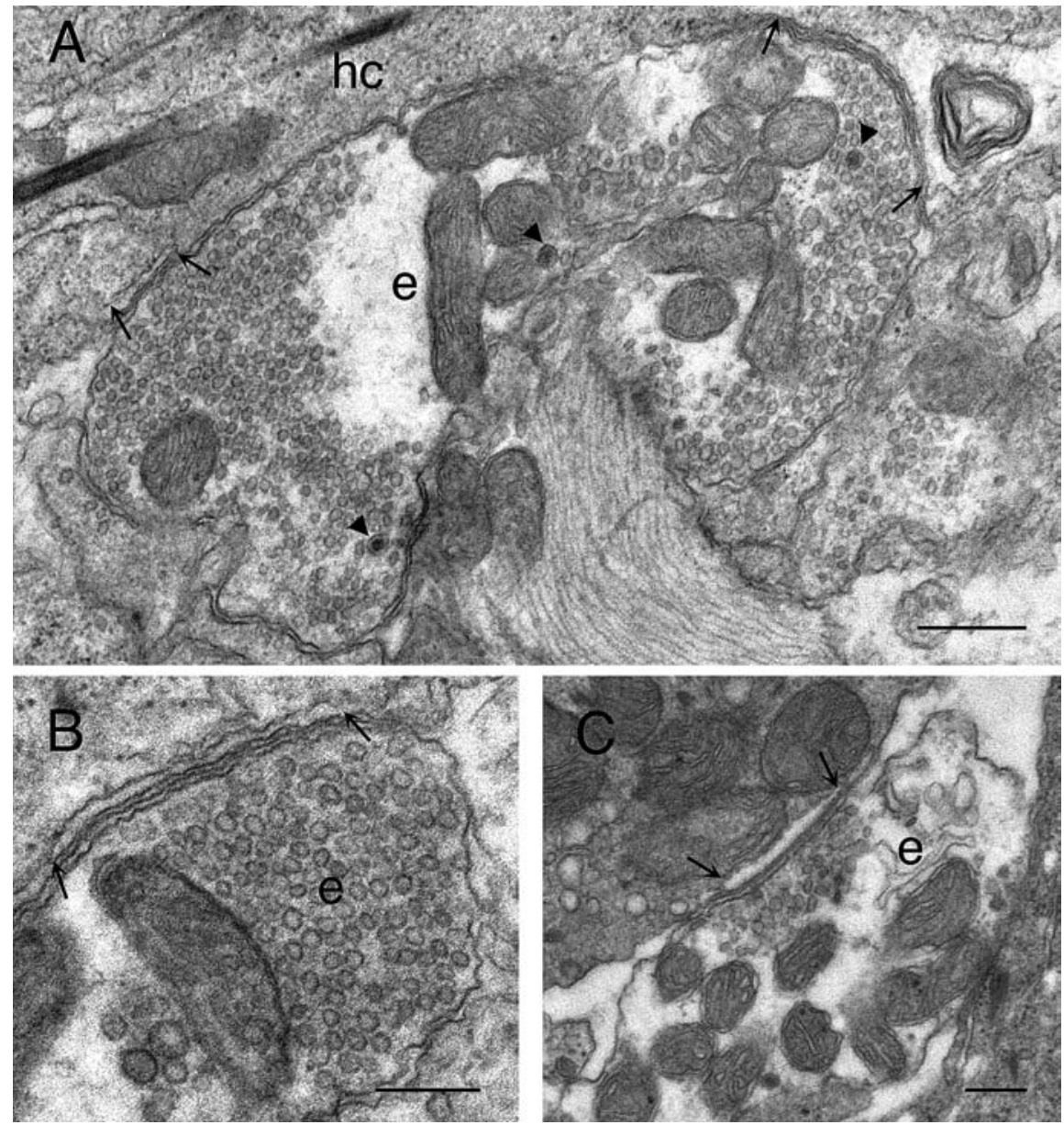


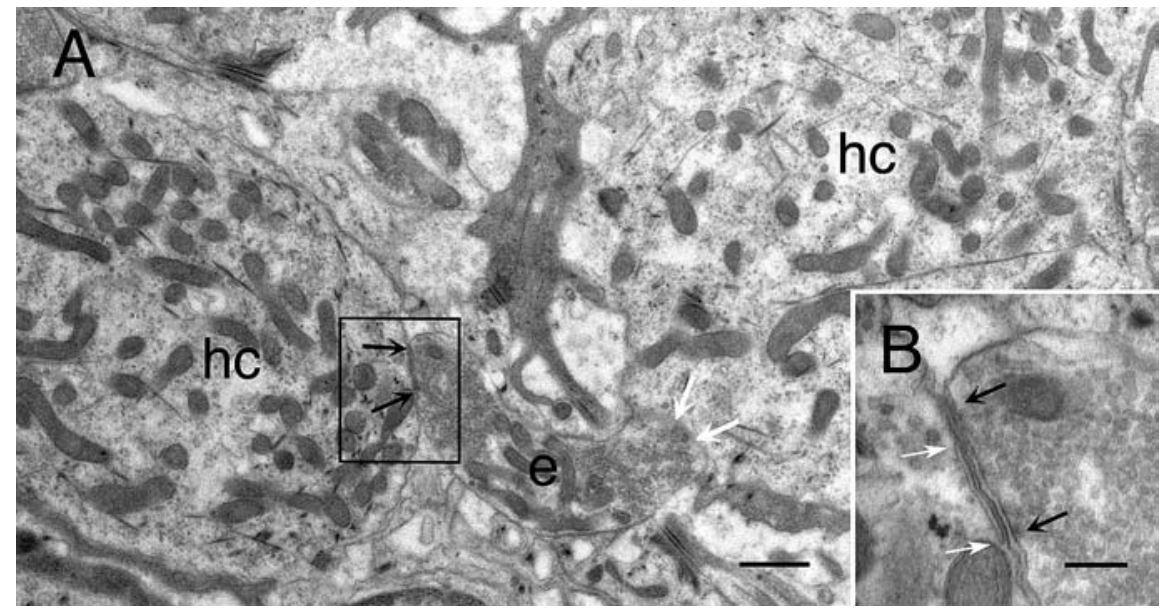

Fig. 5. A A cup-shaped efferent bouton (e) contacting two hair cells $(h c)$ (black and white arrows) in the peripheral crista. Most of the mitochondria in the terminal are concentrated in the concavity of the profile, with vesicles filling the rim. The synaptic region delineated by the rectangle in $\mathbf{A}$ is shown at higher magnification in B, where a narrow subsynaptic cistern and densely packed lucent synaptic vesicles are more clearly visible. The postsynaptic location

tend to cluster in one region of the profile, away from the synaptic vesicle pool (Figs. 3 and 4).

The majority of efferent boutons are spherical or oval, although barbell-, cup-, paddle- and mushroom-shaped terminals are also present (Figs. 2, 3 and 4). The endings provide multiple inputs to individual hair cells (Fig. 4A) and to two neighboring hair cells in single or adjacent thin sections (Fig. 5).

The synaptic contacts between efferent boutons and hair cells tend to be small in all dimensions, $\sim 100-150 \mathrm{~nm}$ thick, with a $50-\mathrm{nm}$ wide synaptic cleft. Subsynaptic cisterns are present in the hair cells at regions of synaptic contact (Figs. 4, 5 and 6), although the postsynaptic location of the cistern is often offset or incompletely coextensive with respect to the presynaptic membrane density (Fig. 5B).

In contrast to the ubiquitous efferent-hair cell synaptic contacts, direct efferent synapses onto afferent processes are less evident in our material. Instead, serial synapses are frequently observed in which a hair cell receives efferent innervation through a cisternal synapse and in turn contacts an afferent neurite at an adjacent synapse (Figs. 6 and 7). These latter contacts are usually characterized by one or more large synaptic bodies surrounded by annuli of lucent vesicles in the presynaptic hair cells. The serial synapses are common in the central crista: a hair cell-afferent synapse is present in the same or an adjacent thin section in approximately $40 \%$ of the sample of efferent-hair cell contacts. However, these serial synaptic arrays are present in less than $10 \%$ of the sample of efferent-hair cells contacts in the peripheral crista.

At some serial synapses, a row of vesicles can be seen in the efferent terminal at the apposed membranes of the efferent and afferent endings (Fig. 8). Although occasional dense core vesicles were present in efferent terminals in the peripheral crista, they were more common in the of the cistern is incompletely co-extensive with respect to the presynaptic membrane density. The white arrows in $\mathbf{B}$ indicate the extent of the subsynaptic cistern in the hair cell and the black arrows indicate the extent of the synaptic contact region where there is a local accumulation of vesicles adherent to the presynaptic membrane. Scale bars: $1 \mu \mathrm{m}$ in $\mathbf{A}, 0.25 \mu \mathrm{m}$ in $\mathbf{B}$

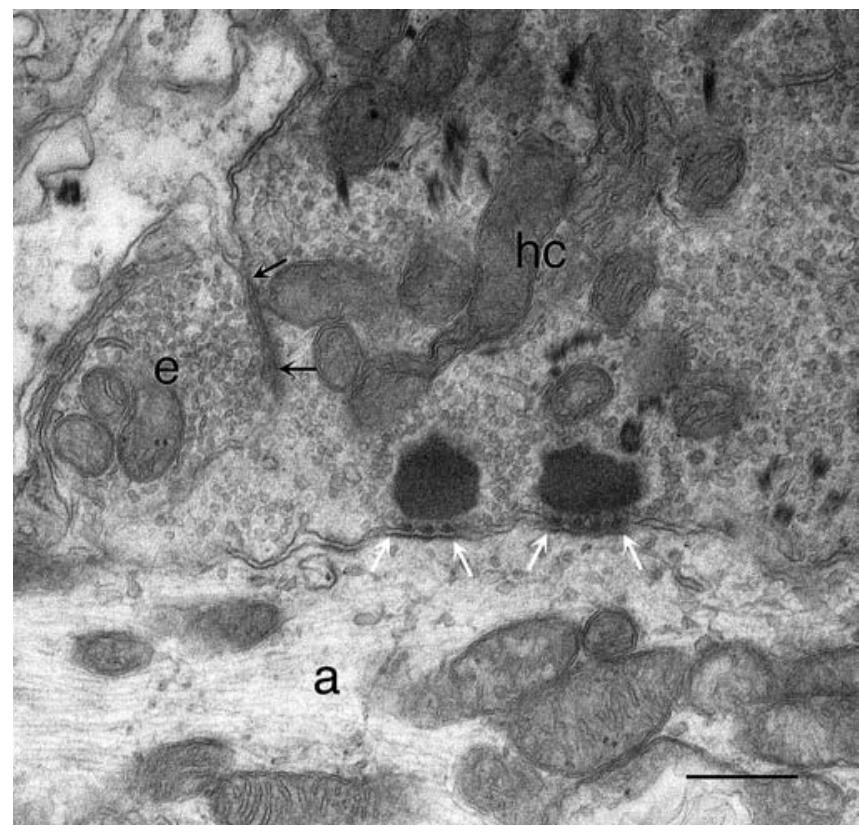

Fig. 6 A serial synaptic contact in the central crista. The efferent terminal $(e)$ contacts a hair cell $(h c)$ through a subsynaptic cistern (black arrows). The hair cell, in turn, forms a synapse with an afferent neuritic process $(a)$ at a nearby junction marked by the presence of synaptic bodies (white arrows). Presynaptic coated vesicles are present at the $\mathrm{HC}$-afferent contact sites. Scale bar: $0.5 \mu \mathrm{m}$

central crista in general, and particularly in those efferents which had direct membrane appositions with afferents. However, such contacts comprised less than $10 \%$ of the total population of efferent synapses. 


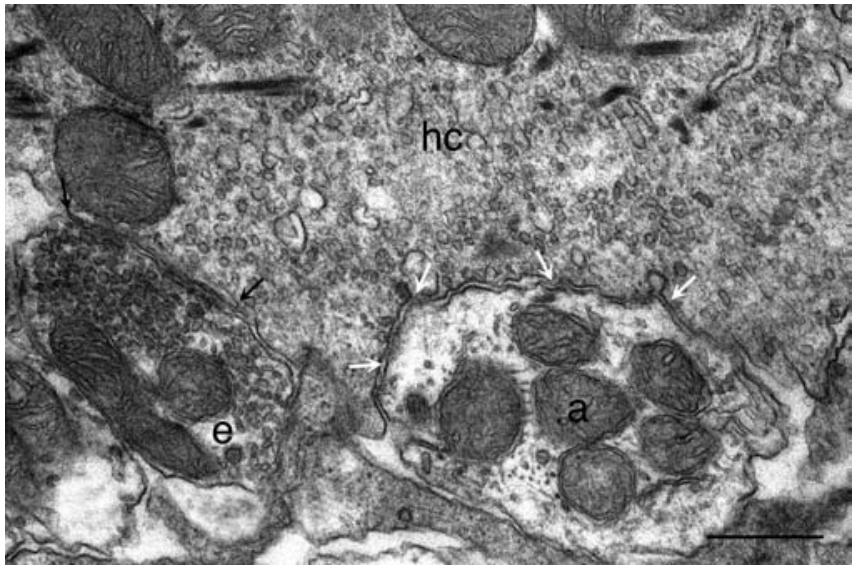

Fig. 7 A serial synapse in the central crista. The efferent terminal (e) contacts a hair cell with a long, narrow subsynaptic cistern (black arrows). The hair cell contacts an afferent neurite (a) through two synapses (white arrows) characterized by vesicles adherent to, or fused with, the presynaptic membrane and the presence of postsynaptic densities at the contact sites. Scale bar: $0.5 \mu \mathrm{m}$

\section{Discussion}

The present study describes the ultrastructural features of efferent boutons in the toadfish horizontal canal crista. These boutons are of variable shape and size, and contain a heterogeneous population of lucent vesicles with scattered dense core vesicles. Efferent contacts with hair cells are characterized by the presence of a local accumulation of vesicles in the presynaptic terminal and a subsynaptic cistern in the postsynaptic region of the hair cell. Serial efferent-hair cell-afferent synaptic arrays are common, particularly in the central portion of the crista. Surprisingly, however, direct contacts between efferent terminals and afferent neurites are not observed in our specimens, although the vesicle accumulations and membrane associations at some efferent-afferent junctions suggest a nonsynaptic, secretory basis for intercellular communication (Verhage et al. 1991; Golding 1994; Leenders et al. 1999).

The efferent pathway has been recognized in a wide variety of mammalian and non-mammalian vertebrates, including rat (Schwarz et al. 1986), guinea pig (Strutz 1982), gerbil (Perachio and Kevetter 1989), cat (Gacek and Lyon 1974), chinchilla (Lysakowski and Goldberg 1997), and squirrel monkey (Goldberg and Fernández 1980), as well as birds (Whitehead and Morest 1981), reptiles (Roberts and Meredith 1992), amphibians (Fritzsch et al. 1984) and fish (Fritzsch et al. 1989), including toadfish (Highstein and Baker 1986), although such a pathway has not been observed in the primitive vertebrate hagfish (Baird 1974a, b). The fibers originate from cells in the medulla which are located between the vestibular and abducens nuclei in mammals and in the vicinity of the facial motor nucleus in non-mammalian vertebrates (for review, see Goldberg et al. 2000). In the toadfish, two groups of efferent cell bodies have been identified: fusiform neurons located dorsal to the medial longitudinal fasciculus and pyramidal neurons situated

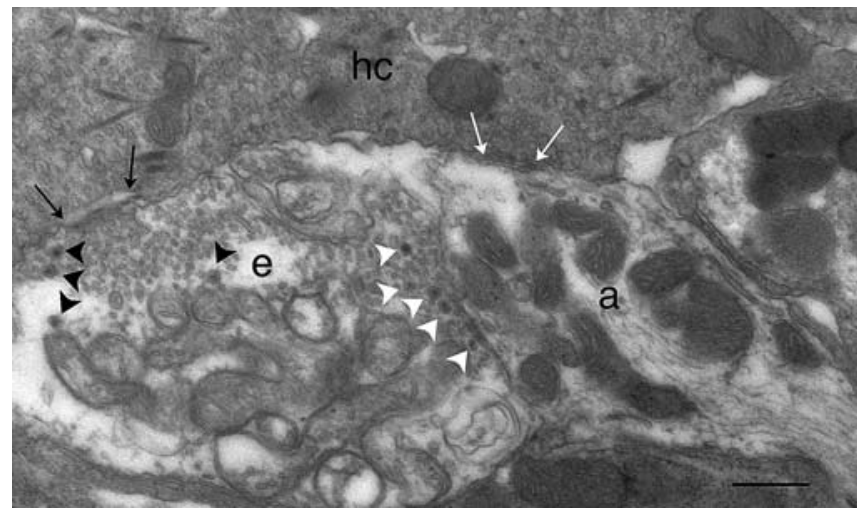

Fig. 8 Serial synapse with efferent-afferent membrane apposition in the central crista. The efferent terminal $(e)$ contacts a hair cell with a subsynaptic cistern (black arrows). The hair cell contacts an afferent neurite (a) through an adjacent specialization (white arrows). Occasional scattered dense core vesicles are present in the efferent terminals (black arrowheads). In addition, a row of such vesicles lines the efferent-afferent membrane apposition (white arrowheads). Scale bar: $0.5 \mu \mathrm{m}$

lateral to that tract (Highstein 1991). A similar pair of efferent brainstem nuclei has been reported in frog (Birinyi et al. 2001).

The ultrastructural features of the efferent terminals are remarkably similar among vertebrates (Lysakowski 1996). In general, the boutons contain a variable density of small, clear, round synaptic vesicles together with occasional larger dense core vesicles. The small clear vesicles are likely to contain acetylcholine (ACh), which has been demonstrated to be at least one of the efferent neurotransmitters (for review, see Guth et al. 1998). Similarly, the dense core vesicles are thought to contain neuroactive peptide transmitters or modulators, most likely calcitonin gene-related peptide (Tanaka et al. 1988, 1989; Wackym et al. 1991, 1993), enkephalins (Carpenter et al. 1987; Perachio and Kevetter 1989) and/or substance P (Usami et al. 1991). Thus, there is no clear correlation between these two efferent cell groups and peripheral bouton morphology.

The efferent terminals form synaptic contacts with type II hair cells, and with both calyx and bouton afferent endings in amniotes (Smith and Rasmussen 1968; Iurato et al. 1972; Wersäll and Bagger-Sjöbäck 1974). Although direct efferent innervation of afferent processes has been reported in some fish (Nakajima and Wang 1974; Sans and Highstein 1984; Lanford and Popper 1996; Lysakowski 1996), they have not been observed in frog (Lysakowski 1996) or in the material for the present report. Efferent contacts with hair cells lack pronounced synaptic membrane densities, but are distinguished by a subsynaptic cistern in the hair cell cytoplasm opposite the presynaptic bouton. Such cisterns are not present at efferent synapses onto afferent processes (Iurato et al. 1972). In summary, the fine structure of the efferent boutons in the toadfish is indistinguishable from that of other vertebrates. However, the synaptology of these endings has several unique attributes, most notably the serial synaptic arrays that are 
common in the central crista and the vesicle accumulations at serial synaptic efferent-afferent membrane appositions.

In a previous study of the toadfish vestibular periphery (Sans and Highstein 1984), efferent synapses onto hair cells were reported to involve terminals with round synaptic vesicles and electron-dense particles. Other efferent terminals, with smaller round lucent microvesicles and some dense core vesicles, directly contacted afferent endings. These direct efferent-afferent contacts were apparently quite common. These findings differ in several respects from our present observations. Although the vesicle population in the efferent boutons in our material shows some variability in size and marked differences in shape, there is no correlation between vesicle morphology and other anatomical attributes of the endings. In addition, no electron dense particles are present in a particular class of efferent boutons in our study, and no microvesicles are observed. Although these differences could be attributable to alternative tissue fixation or processing approaches, our failure to find direct efferent-afferent contacts is less likely to be due to methodologic issues. Even assuming that some such contacts exist in the toadfish but were overlooked in our study, it is very unlikely that this synaptology comprises a significant synaptic population since our sampling strategy encompassed the entire extent of the epithelium. It is most likely that the disparate results are due to differences in synaptology between sensory organs. In fact, Nakajima and Wang examined tissue from the goldfish saccule, and Sans and Highstein pooled data from the utricular macula and the crista ampullaris. While the latter investigators report that the ultrastructural features were generally similar, it is not possible to determine what impact this tissue pooling may have had on their observations. At present, we interpret the disparities between our present findings and theirs to be due to this tissue pooling, and speculate that direct efferent-afferent contacts are concentrated in the otolith organs of the toadfish. The serial efferent-hair cell-afferent synapses, though not previously reported, are quite prevalent in our material, particularly in the central region of the crista. The existence of these contacts, and the row of vesicles in the efferent boutons lining the efferent afferent membrane apposition, suggests that the efferent influence on the crista may involve both synaptic and nonsynaptic, secretory mechanisms.

Efferent activation of vestibular hair cells in the toadfish produces large hyperpolarizing postsynaptic potentials, decreases membrane resistance, and decreases the hair cell receptor potential modulation in response to canal stimulation (Boyle et al. 1997). Concomitantly, the afferent firing rate increases, and the gain in response to adequate stimulation decreases (Boyle and Highstein 1990; Boyle et al. 1998). In the toadfish (Highstein and Baker 1985; Boyle and Highstein 1990), as in turtle (Brichta and Goldberg 1996, 2000) and frog (Rossi et al. 1980, 1994 Bernard et al. 1985; Rossi and Martini 1991), afferents innervating the peripheral crista are less sensitive to efferent stimulation than those innervating the central torus region, although the polarity of that sensitivity, excitation or inhibition, is variable. Similarly, in cat (McCue and Guinan 1994) and chinchilla (Plotnik et al. 2002), afferent discharges associated with processes innervating the central crista appear to be more responsive to efferent stimulation. It is unlikely that the regional differences in efferent response to afferent stimulation are attributable to differences in the efferent innervation density per se (Purcell and Perachio 1997). However, it is very likely that differences in other, more subtle aspects of synaptic architecture and/or transmitter and receptor localization and interaction may underlie this behavior, rendering the efferent innervation of the peripheral crista less effective in influencing sensory processing. The presence of a substantial direct efferent innervation of peripheral hair cells is a further puzzle, given that the responses of low gain afferents to adequate stimulation are only slightly reduced by efferent activation. This suggests that the EVS may serve multiple functions, in addition to its role in reducing the responses to head velocity.

It is conceivable that structural aspects of the subsynaptic cisterns at efferent-hair cell junctions support regional differences in $\mathrm{Ca}^{2+}$ concentration (Miller 1991), since longer cisternal pockets may provide greater storage capacity, and therefore also greater local $\mathrm{Ca}^{2+}$ buffering capability in the microenvironment of the efferent synapse. In fact, activation of sympathetic ganglion cell cisternal synapses causes $\mathrm{Ca}^{2+}$ release from the cisternae, opening $\mathrm{Ca}^{2+}$-activated $\mathrm{K}^{+}$channels and thereby hyperpolarizing the cell (Fujimoto et al. 1980). Moreover, application of ACh, a putative efferent neurotransmitter, on isolated cochlear hair cells produces an outward $\mathrm{K}^{+}$current and membrane hyperpolarization (Fuchs and Murrow 1992). These findings suggest that $\mathrm{Ca}^{2+}$ is released from intracellular stores and causes increased $\mathrm{K}^{+}$conductance. In this framework, the efferent vestibular pathway would regulate hair cell threshold and gain by controlling intracellular $\mathrm{Ca}^{2+}$ release from the cisternae, and therefore $\mathrm{Ca}^{2+}$ activated $\mathrm{K}^{+}$conductance (Shigemoto and Ohmori 1990; Fuchs and Murrow 1992; Yamashita et al. 1993). If so, then differences in cisternal size would predict regional differences in $\mathrm{Ca}^{2+}$ storage capabilities, as well as more generally in the regulation of cytosolic free $\mathrm{Ca}^{2+}$ concentration.

Another possible role for the subsynaptic cisterns may be purely architectural. It has been noted that $\mathrm{Ca}^{2+}$ traverses the hair cell basal plasma membrane through a variety of receptor- and membrane-associated channels (Fuchs 2002). Although ACh also raises the $\mathrm{Ca}^{2+}$ concentration in the intracellular cytosolic pool, afferent and efferent synaptic $\mathrm{Ca}^{2+}$ signals are probably segregated in the hair cell (Lenzi and Roberts 1994). In this context, the cisterns may serve to maintain this independence by providing a diffusion barrier as well as an intracellular storage compartment (Fuchs 1996; Guth et al. 1998) to both supply and sequester $\mathrm{Ca}^{2+}$ (Guth et al. 1998; Rispoli et al. 2001). 
Acknowledgements The authors are grateful to Ms. Rosemary Lang for technical help with various aspects of this work. This research was supported by the National Institute for Deafness and Other Communication Disorders Grant PO1 DC-01837.

\section{References}

Baird IL (1974a) Anatomical features of the inner ear in submammalian vertebrates. In: Keidel WD, Neff W (eds) Handbook of sensory physiology. Springer, Berlin, Heidelberg, New York, pp 159-212

Baird IL (1974b) Some aspects of the comparative anatomy and evolution of the inner ear in submammalian vertebrates. Brain Behav Evol 10:11-36

Bernard C, Cochran SL, Precht W (1985) Presynaptic actions of cholinergic agents upon the hair cell-afferent synapse in the vestibular labyrinth of the frog. Brain Res 338:225-236

Birinyi A, Straka H, Matesz C, Dieringer N (2001) Location of dyecoupled second order and of efferent vestibular neurons labeled from individual semicircular canal or otolith organs in the frog. Brain Res 921:44-59

Boyle R, Highstein SM (1990) Efferent vestibular system in the toadfish: action upon horizontal semicircular canal afferents. J Neurosci 10:1570-1582

Boyle R, Carey JP, Highstein SM (1991) Morphological correlates of response dynamics and efferent stimulation in horizontal semicircular canal afferents of the toadfish, Opsanus tau. J Neurophysiol 66:1504-1521

Boyle R, Highstein SM, Rabbitt RD (1997) Efferent action on semicircular canal hair cells in situ in the toadfish, Opsanus tau. Assoc Res Otolaryngol Midwintr Res. meeting abstracts 20:34

Boyle R, Highstein SM, Rabbitt RD (1998) Simultaneous recordings from individual hair cells and afferents during mechanical canal and efferent stimulation in vivo in the toadfish. Soc Neurosci Abst 24:1399

Brichta AM, Goldberg JM (1996) Afferent and efferent responses from morphological fiber classes in the turtle posterior crista. Ann NY Acad Sci 781:183-195

Brichta AM, Goldberg JM (2000) Responses to efferent activation and excitatory response-intensity relations of turtle posteriorcanal afferents. J Neurophysiol 83:1224-1242

Carpenter MB, Chang L, Pereira AB, Hersh LB, Bruce G, Wu J-Y (1987) Vestibular and cochlear efferent neurons in the monkey identified by immunocytochemical methods. Brain Res 408:275-280

Chang JSY, Popper AN, Saidel WM (1992) Heterogeneity of sensory hair cells in a fish ear. J Comp Neurol 324:621-640

Engström H (1960) The innervation of the vestibular sensory cells. Acta Otolaryngol 163[Suppl]: 30-41

Engström H (1970) The first-order vestibular neuron. In: Fourth symposium on the role of the vestibular organs in space exploration. US Govt. Printing Office (NASA SP-187), Washington, D.C., pp 123-134

Flock A (1964) Structure of the macula utriculi with special reference to directional interplay of sensory responses as revealed by morphological polarization. J Cell Biol 22:413-431

Fritzsch B, Crapon DE, Caprona D (1984) The origin of centrifugal inner ear fibers of gymnophions (amphibia). A horseradish peroxidase study. Neurosci Lett 45:131-145

Fritzsch B, Dubuc R, Ohta Y, Grillner S (1989) Efferents to the labyrinth of the river lamprey (Lampetra fluiatilis) as revealed with retrograde tracing techniques. Neurosci Lett 96:241-252

Fuchs PA (1996) Synaptic transmission at vertebrate hair cells. Curr Opin Neurobiol 6:514-519

Fuchs PA (2002) The synaptic plasticity of cochlear hair cells. Audiol Neurootol 7:40-44

Fuchs PA, Murrow BW (1992) Cholinergic inhibition of short (outer) hair cells of the chick's cochlea. J Neurosci 12:800-809
Fujimoto S, Yamamoto K, Kuba K, Morita K, Kato E (1980) Calcium localization in the sympathetic ganglion of the bullfrog and effects of caffeine. Brain Res 202:21-32

Gacek RR, Lyon M (1974) The localization of vestibular efferent neurons in the kitten with horseradish peroxidase. Acta Otolaryngol Scand 77:92-101

Gleisner L, Flock A, Wersall J (1973) The ultrastructure of the afferent synapse on hair cells in the frog labyrinth. Acta Otolaryngol 76:199-207

Goldberg JM, Fernández C (1980) Efferent vestibular system in the squirrel monkey: anatomical location and influence on afferent activity. J Neurophysiol 43:986-1025

Goldberg JM, Brichta AM, Wackym PA (2000) Efferent vestibular system: Anatomy, physiology, and neurochemistry. In: Beitz AJ, Anderson JH (eds) Neurochemistry of the vestibular system. CRC Press, Boca Raton, pp 61-94

Golding DW (1994) A pattern confirmed and refined-synaptic, nonsynaptic and parasynaptic exocytosis. Bioessays 16:503508

Guth PS, Perin P, Norris CH, Valli P (1998) The vestibular hair cells: post-transductional signal processing. Prog Neurobiol 54:193247

Hama K (1965) Some observations on the fine structure of the lateral line organ of the Japanese sea eel, Lyncozyma nystromi. J Cell Biol. 24:193-210

Hama K (1969) A study on the fine structure of the saccular macula of the goldfish. Z Zellforsch 94:155-171

Hamilton DW (1968) The calyceal synapse of type I vestibular hair cells. J Ultrastruct Res 23:98-114

Highstein SM (1991) The central nervous system efferent control of the organs of balance and equilibrium. Neurosci Res 12:13-30

Highstein SM, Baker R (1985) The action of the efferent vestibular system upon primary afferents of the toadfish, Opsanus tau. J Neurophysiol 54:370-384

Highstein SM, Baker R (1986) Organization of the efferent vestibular nuclei and nerves of the toadfish, Opsanus tau. J Comp Neurol 243:309-325

Holstein G, Highstein SM (1999) Ultrastructural observations of efferent synapses with peripheral hair cells in the crista ampullaris of the toadfish, Opsanus tau. In: Association for Research in Otolaryngology, Midwinter Research Meeting

Holstein GR, Boyle R, Highstein SM, Martinelli GP (2000) Ultrastructure of efferent boutons and synapses in the central and peripheral crista ampullaris of the horizontal semicircular canal of the toadfish. In: Association for Research in Otolaryngology, Midwinter Research Meeting

Iurato S, Luciano L, Pannese E, Reale E (1972) Efferent vestibular fibers in mammals: morphological and histochemical aspects. In: Brodal A, Pompeiano O (eds) Basic aspects of central vestibular mechanisms, vol 37. Elsevier, Amsterdam, pp 429 443

Jenkins DB (1979) A transmission and scanning electron microscopic study of the saccule in five species of catfishes. Am J Anat 154:81-102

Lanford PJ, Popper AN (1996) Novel afferent terminal structure in the crista ampullaris of the goldfish, Carassius auratus. J Comp Neurol 366:572-579

Leenders AG, Scholten G, Wiegant VM, Da Silva FH, Ghijsen WE (1999) Activity-dependent neurotransmitter release kinetics: correlation with changes in morphological distributions of small and large vesicles in central nerve terminals. Eur J Neurosci 11:4269-4277

Lenzi D, Roberts WM (1994) Calcium signalling in hair cells: multiple roles in a compact cell. Curr Opin Neurobiol 4:496502

Lowenstein O, Osborne MP, Thornhill RA (1968) The anatomy and ultrastructure of the labyrinth of the lamprey. Proc R Soc B 170:113-134

Lysakowski A (1996) Synaptic organization of the crista ampullaris in vertebrates. In: Highstein SM, Cohen B, Büttner-Ennever J (eds) Ann NY Acad Sci, vol 781. New York Academy of Sciences, New York, pp 164-182 
Lysakowski A, Goldberg JM (1997) A regional ultrastructural analysis of the cellular and synaptic architecture in the Chinchilla cristae ampullares. J Comp Neurol 389:419-443

McCue MP, Guinan JJJ (1994) Influence of efferent stimulation on acoustically responsive vestibular afferents in the cat. J Neurosci 14:6071-6083

Miller RJ (1991) The control of neuronal Ca2+ homeostasis. Prog Neurobiol 37:255-285

Nakajima Y, Wang DA (1974) Morphology of afferent and efferent synapses in hearing organ of the goldfish. J Comp Neurol 156:403-416

Perachio AA, Kevetter GA (1989) Identification of vestibular efferent neurons in the gerbil: histochemical and retrograde labelling. Exp Brain Res 78:315-326

Plotnik M, Marlinski V, Goldberg JM (2002) Reflections of efferent activity in rotational responses of chinchilla vestibular afferents. J Neurophysiol 88:1234-1244

Popper AN (2000) Hair cell heterogeneity and ultrasonic hearing: recent advances in understanding fish hearing. Phil Trans Roy Soc Lond B 355:1277-1280

Purcell IM, Perachio AA (1997) Three-dimensional analysis of vestibular efferent neurons innervating semicircular canals of the gerbil. J Neurophysiol 78:3234-3248

Rispoli G, Martini M, Rossi ML, Mammano F (2001) Dynamics of intracellular calcium in hair cells isolated from the semicircular canal of the frog. Cell Calcium 30:131-140

Roberts BL, Meredith GE (1992) The efferent innervation of the ear: variations on an enigma. In: Fay RA, Popper AN, Webster DB (eds) The evolutionary biology of hearing. Springer, Berlin, Heidelberg, New York, pp 185-210

Ross MD (1997) Morphological evidence for local microcircuits in rat vestibular maculae. J Comp Neurol 379:333-346

Ross MD, Rogers CM, Donovan KM (1985) Innervation patterns in rat saccular macula. Acta Otolaryngol 102:75-86

Rossi ML, Martini M (1991) Efferent control of posterior canal afferent receptor discharge in the frog labyrinth. Brain Res 555:123-134

Rossi ML, Prigioni I, Valli P, Casella C (1980) Activation of the efferent system in the isolated frog labyrinth: effects on the afferent EPSPs and spike discharge recorded from single fibers of the posterior nerve. Brain Res 185:125-137

Rossi ML, Martini M, Pelucchi B, Fesce R (1994) Quantal nature of synaptic transmission at the cytoneural junction in the frog labyrinth. J Physiol (Lond) 478:17-35

Russell IJ (1971) the role of the lateral line efferent system in Xenopus laevis. J Exp Biol 54:621-641

Saidel WM, Crowder JA (1997) Expression of cytochrome oxidase in hair cells of the teleost utricle. Hearing Res 109:63-77

Saidel WM, Presson J (1990) S-100 immunoreactivity identifies a subset of hair cells in the utricle and saccule of a fish. Hearing Res 47

Saidel WM, Popper AN, Chang JS (1990) Spatial and morphological differentiation of trigger zones in afferent fibers to the teleost utricle. J Comp Neurol 302:629-642

Sans A, Highstein SM (1984) New ultrastructural features in the vestibular labyrinth of the toadfish, Opsanus tau. Brain Res 308:191-195

Schwarz DWF, Satoh L, Schwarz IE, Hu K, Fibiger HC (1986) Cholinergic innervation of the rat's labyrinth. Exp Brain Res 64:19-26
Shigemoto T, Ohmori H (1990) Muscarinic agonists and ATP increase the intracellular $\mathrm{Ca} 2+$ concentration in chick cochlear hair cells. J Physiol (Lond) 420:127-148

Smith CA, Rasmussen GL (1968) Nerve endings in the maculae and cristae of the chinchilla vestibule, with a special reference to the efferents. In: Third symposium on the role of the vestibular organs in space exploration, vol SP-152. US Govt. Printing Office, Washington, D.C., pp 183-201

Smith CA, Sjostrand F (1961) A synaptic structure in the hair cells of the guinea pig cochlea. J Ultrastruct Res 5:184-192

Spoendlin H (1965) Ultrastructural studies of the labyrinth in squirrel monkeys. In: Graybiel A (ed) The role of the vestibular organs in the exploration of space, vol SP-77. NASA, Washington, D.C., pp 7-21

Strutz J (1982) The origin of efferent vestibular fibers in the guinea pig. Acta Otolaryngol 94:299-302

Tanaka M, Takeda N, Senba E, Tohyama M, Kubo T, Matsunaga T (1988) Localization of calcitonin gene-related peptide in the vestibular endorgans in the rat: an immunohistochemical study. Brain Res 447:175-177

Tanaka M, Takeda N, Senba E, Tohyama M, Kubo T, Matsunanga T (1989) Localization, origin, and fine structure of calcitonin gene-related peptide-containing fibers in the vestibular endorgans of the rat. Brain Res 504:31-35

Usami S-I, Hozawa J, Ylikoski J (1991) Coexistence of Substance P and calcitonin gene-related peptide-like immunoreactivities in the rat vestibular endorgans. Acta Otolaryngol (Stockh) 481 [Suppl]: 166-169

Verhage M, McMahon HT, Ghijsen WE, Boomsma F, Scholten G, Wiegant VM, Nicholls DG (1991) Differential release of amino acids, neuropeptides, and catecholamines from isolated nerve terminals. Neuron 6:517-524

Wackym PA, Popper P, Ward PH, Micevych P-E (1991) Cell and molecular anatomy of nicotinic acetylcholine receptor subunits and calcitonin gene-related peptide in the rat vestibular system. Otolaryngol Head Neck Surg 105:493-510

Wackym PA, Popper P, Micevych PE (1993) Distribution of calcitonin gene-related peptide mRNA and immunoreactivity in the rat central and peripheral vestibular system. Acta Otolaryngol (Stockh) 113:601-608

Wegner N (1982) A qualitative and quantitative study of a sensory epithelium in the inner ear of a fish (Colisa labiosa; Anabantidae). Acta Zool 63:133-146

Wersäll J (1954) The minute structure of the crista ampullaris in the guinea pig as revealed by the electron microscope. Acta Otolaryngol 44:359-369

Wersäll J (1960) Vestibular receptor cells in fish and mammals. Acta Otolaryngol 163[Suppl]: 25-29

Wersäll J, Bagger-Sjöbäck D (1974) Morphology of the vestibular sense organ. In: Kronhuber HH (ed) Handbook of sensory physiology: the vestibular system, Part 1: basic mechanisms. Springer, Berlin, Heidelberg, New York, pp 123-170

Whitehead MC, Morest DK (1981) Dual populations of efferent and afferent cochlear axons in the chicken. Neurosci 6:2351

Yamashita T, Ohnishi S, Ohtani M, Kumazawa T (1993) Effects of efferent neurotransmitters of intracellular $\mathrm{Ca}^{2+}$ concentration in vestibular hair cells of the guinea pig. Acta Otolaryngol (Stockh) 500[Suppl]: 26-30 